\title{
Developing Citrus Huanglongbing (HLB) Management Strategies Based on the Severity of Symptoms in HLB-Endemic Citrus-Producing Regions
}

\author{
Jinyun Li, ${ }^{1}$ Lei Li, ${ }^{1,3}$ Zhiqian Pang, ${ }^{1}$ Vladimir G. Kolbasov, ${ }^{1}$ Reza Ehsani, ${ }^{4}$ Erica W. Carter, ${ }^{5}$ and Nian Wang ${ }^{1,2, \dagger}$ \\ ${ }^{1}$ Citrus Research and Education Center, Department of Microbiology and Cell Science, University of Florida, 700 Experiment Station Road, \\ Lake Alfred 33850, U.S.A.; ${ }^{2}$ China-USA Citrus Huanglongbing Joint Laboratory (A joint laboratory of The University of Florida's Institute of \\ Food and Agricultural Sciences and Gannan Normal University), National Navel Orange Engineering Research Center, Gannan Normal \\ University, Ganzhou, Jiangxi, China; ${ }^{3}$ Institute of Vegetables and Flowers, Chinese Academy of Agricultural Sciences, Beijing 100081, China; \\ ${ }^{4}$ Department of Mechanical Engineering, University of California, Merced, 5200 N. Lake Road, SE2-282, Merced 95343, U.S.A.; and ${ }^{5}$ Citrus \\ Research and Education Center, Department of Plant Pathology, University of Florida, 700 Experiment Station Road, Lake Alfred 33850, U.S.A. \\ Accepted for publication 8 November 2018.
}

\begin{abstract}
Citrus Huanglongbing (HLB), also known as greening, is a destructive disease caused by the fastidious, phloem-colonizing bacteria Candidatus Liberibacter spp.; 'Ca. Liberibacter asiaticus' (Las) is the most prevalent of the species causing HLB. The Asian citrus psyllid (ACP, Diaphorina citri) transmits Las. HLB is threatening citrus production worldwide, and there is no cure for infected trees. Management strategies targeting diseased trees at different stages of colonization by Las are needed for sustainable citrus production in HLB-endemic regions. We evaluated the effect of the combinations of plant defense elicitors, nitrogen $(\mathrm{N})$ fertilizer, and compost on mildly diseased trees. We tested thermotherapy on severely diseased trees and assessed tree protectors to prevent feeding by ACP, thus preventing Las from being transmitted to new plantings that replaced HLB-moribund trees. After four applications over two consecutive growing seasons we found that the

approximately $18 \%$, compared with the untreated control. Our data showed no decline in fruit yield, indeed treatment resulted in a higher yield compared with the untreated control. Thermotherapy treatment $\left(55^{\circ} \mathrm{C}\right.$ for $\left.2 \mathrm{~min}\right)$ exhibited a suppressive effect on growth of Las and progress of HLB in severely diseased trees for 2 to 3 months after treatment. The tree protectors prevented feeding by ACP, and therefore young replant trees remained healthy and free from infection by Las over the 2-year duration of the experiment. Taken together, these results may contribute to a basis for developing a targeted approach to control HLB based on stage of host colonization, application of plant defense elicitors, $\mathrm{N}$ fertilizer, compost, thermotherapy, and tree protectors. There is potential to implement these strategies in conjunction with other disease control measures to contribute to sustainable citrus production in HLB-endemic regions.
\end{abstract} combination of compost, urea, and plant defense elicitors $\beta$-aminobutyric acid, plus ascorbic acid and potassium phosphite with or without salicylic acid, slowed down the progression of HLB and reduced disease severity by
Keywords: citrus disease control, Huanglongbing, HLB, integrated management, Liberibacter.
Huanglongbing (HLB), also called citrus greening, is the most devastating disease of citrus and causes economic losses in many citrus growing regions of the world (Bové 2006; Gottwald et al. 2007; Wang and Trivedi 2013; Wang et al. 2017). The disease is associated with three uncultured phloem-residing species of 'Candidatus Liberibacter': 'Ca. L. asiaticus' (Las), 'Ca. L. africanus', and ' $\mathrm{Ca}$. L. americanus', which are transmitted by two psyllid vectors: the Asian citrus psyllid (ACP) (Diaphorina citri Kuwayama) and the African citrus psyllid (Trioza erytreae (del Guercio)) (Bové 2006). Las is the most virulent and widely distributed species of ' $C a$. Liberibacter' in the world (Wang et al. 2017), and ACP is the vector for Las (Bové 2006). HLB was first reported in Southeast Asia over 100 years ago and was first reported in the western hemisphere in Brazil in 2004 (Coletta-Filho et al. 2004), and later in the Unites States (Florida) in 2005 (Halbert 2005). The disease has spread rapidly and expanded to most commercial citrus production areas throughout the world, except

\section{${ }^{\dagger}$ Corresponding author: N. Wang; E-mail: nianwang@ufl.edu}

Funding: This work was supported by the United States Department of Agriculture, Animal and Plant Health Inspection Service (USDA-APHIS) MultiAgency Coordination (MAC) Program, Florida Department of Agriculture and Consumer Service Citrus Initiative Program, and the National Key Research and Development Program of China (2018YFD0201500).

The $\boldsymbol{e}$-Xtra logo stands for "electronic extra" and indicates that two supplementary figures are published online.

(C) 2019 The American Phytopathological Society the Mediterranean region and Australia (Wang et al. 2017). In the Unites States, in addition to Florida, HLB has been confirmed in Louisiana, South Carolina, Georgia, Texas, California, and Alabama (Belcher 2017; Wang and Trivedi 2013).

The disease causes yellowing of shoots, blotchy mottled leaves, corky veins, malformed and discolored fruit, premature fruit drop, root loss, and eventually tree death (Bové 2006; Gottwald et al. 2007; Wang and Trivedi 2013). Infected citrus trees have a dramatically shortened profitable life and significantly reduced yield (Gottwald et al. 2007). Since the initial discovery of HLB in Florida in 2005, the disease has affected most citrus-producing areas, causing the loss of about 100,000 acres of citrus, at a cost of approximately $\$ 3.6$ billion in lost revenues and 6,600 jobs (Alvarez et al. 2016). Currently, it is estimated that Las has infected over $95 \%$ of the mature trees in commercial citrus groves in Florida.

Various control measures have been shown to slow the progress of HLB and help maintain tree productivity under field conditions. These measures include control of psyllid vectors using insecticides (Boina and Bloomquist 2015), enhanced foliar nutritional programs (Rouse et al. 2017; Stansly et al. 2014; Tansey et al. 2017), foliar application of inorganic P solution (Zhao et al. 2013), and application of antibiotics including ampicillin, oxytetracycline, and streptomycin (Hu and Wang 2016; Hu et al. 2018; Yang et al. 2015). In addition, plant defense inducers or activators ( $\mathrm{Hu}$ et al. 2018; Li et al. 2016), soil conditioners (Xu et al. 2013), and thermotherapy (Al-Jumaili and Ehsani 2015; Ehsani et al. 2016) may help reduce the impact of HLB. However, under field conditions the effectiveness of these treatments is often inconsistent or controversial. For example, in one study (Gottwald et al. 2012) no 
differences were observed in tree health, Las titer, fruit quality, and yield between trees treated with an enhanced nutritional program and control trees. In contrast, Shen et al. (2013) reported that the enhanced nutrient program reduced Las titer, while increasing leaf size and weight after at least 3 years of treatment. In addition, a positive effect on citrus fruit yield from foliar nutrients has been observed (Stansly et al. 2014). The contrasting results from different studies indicating contradictory effects may result in part from using citrus plants at different stages of colonization by HLB. It has been shown that induction of plant defense had more effect on young trees with mild HLB compared with old trees with severe symptoms of HLB ( $\mathrm{Li}$ et al. 2016). We hypothesize that HLB management can be improved by targeting HLB-control strategies based on the stage of HLB colonization subsequent to infection.

In commercial citrus groves in Florida, mature, HLB-diseased trees can be classified into three categories as Las colonizes the host, based on progression of symptoms: mild, severe, and dying. Dying trees are generally replaced by replantings. Young plant development is the most critical growth stage to protect citrus trees from HLB because young, newly planted trees are most susceptible to infection by Las and most attractive to ACP, as they flush most frequently and therefore provide sufficient developing shoots for ACP oviposition (Gottwald 2010). Our previous studies demonstrated that $\beta$-aminobutyric acid (BABA), a nonprotein amino acid, consistently reduced the effect of HLB by inducing a plant defense response via priming salicylic acid (SA)-dependent defense mechanisms (Hu et al. 2018; Li et al. 2016; 2017). But induced resistance may be costly to the plant due to metabolic competition between growth and defense (Cipollini et al. 2003). Indeed, it has been reported that healthy wheat treated with benzothiadiazole (BTH) had lower numbers of ears and grains, as well as plant biomass, especially when these treated plants were under nitrogen (N)-limiting stress (Heil et al. 2000). It is possible that application of plant defense inducers for HLB control will result in the same issue affecting plant productivity under $\mathrm{N}$-deficient conditions (Heil et al. 2000), thus limiting their effectiveness in reducing the damage due to HLB. We hypothesize that plant defense inducers with supplementary $\mathrm{N}$ might reduce the impact of HLB in trees with mild symptoms.

Protection of young trees from vector feeding is another option, but available approaches are currently limited. Control of the psyllid vector using insecticides is key to protecting new citrus plantings from infection by Las (Bové 2006; Gottwald et al. 2007; Wang et al. 2017). Unfortunately, the development of insecticide resistance can compromise efficacy (Tiwari et al. 2011). Recently, metalized polyethylene mulch has been shown to repel ACP from young citrus trees and therefore slow spread of HLB (Croxton and Stansly 2014). "Citrus Under Protective Screen" (CUPS) is being tested as a new method to control HLB and has shown promise (Schumann and Singerman 2016). Further investigation using protection is warranted.

Potassium phosphite (Phi) is well known for its activity against various fungal, oomycetes, and bacterial pathogens by inducing resistance in a wide range of plants including citrus (Aćimović et al. 2015; Graham 2011; Walters et al. 2013). Our recent studies showed that trunk-injected Phi exhibited some positive impact against citrus HLB by activating a plant defense response (Hu et al. 2018). We surmise that foliar applied Phi augmented with $\mathrm{N}$ fertilizer might help control HLB in trees with mild symptoms.

The use of compost as a soil amendment in citrus production has resulted in improved tree growth (Ozores-Hampton et al. 2015). Compost may contain beneficial microbes that convert nitrogen and other nutrients into an easily available form for the plant. Therefore, compost is speculated to counteract the loss of nutrient uptake in HLB-diseased citrus caused by root dysfunction (Johnson et al. 2014). Additionally, beneficial bacteria such as Paenibacillus validus and Lysinibacillus fusiformis have been shown to have antimicrobial effects against Las (Trivedi et al. 2011), which may contribute to the effect of the compost. Therefore, we speculate that compost may be a potential HLB management tool and could be integrated with other approaches to help reduce disease progress while increase or maintain yield of HLB-diseased citrus under field conditions.

There is no single cure or method to control HLB (National Academies of Sciences, Engineering, and Medicine 2018). In newly infected citrus-producing areas such as California, eradication to remove sources of inoculum are being implemented to prevent HLB from becoming endemic (Wang et al. 2017). In HLB-endemic regions such as Florida, eradication has only limited effect in preventing spread of HLB due to the high incidence of disease and the long, variable asymptomatic incubation period (Lee et al. 2015). Survival of the Florida citrus industry and other HLB endemic citrus producing regions requires maintaining the productivity of mildly diseased trees and new plantings to increase overall production.

This study aimed to present a targeted approach to management and control of HLB based on the stage of colonization. The objectives were to evaluate (i) different combinations of plant defense inducers, $\mathrm{N}$ fertilizer, and compost for control of HLB in trees with mild symptoms, (ii) thermotherapy for control of HLB in citrus trees with severe symptoms, and (iii) tree protectors for preventing replants from becoming infected with Las.

\section{MATERIALS AND METHODS}

Evaluation of the effect of plant defense inducers, nitrogen fertilizer, and compost on citrus HLB in category 1 trees with mild symptoms. Field sites and experimental design. Two field trials were conducted independently in a commercial grove located in Lake Wales, Florida (Trial I) from 2014 to 2016 and in a grove at the Mid-Florida Citrus Research Foundation located in central Florida (Trial II) from 2015 to 2017. In Trial I, the experiments were performed with 12-year-old Murcott mandarin (Citrus reticulata (L.) Blanco) on Cleopatra mandarin (Citrus reticulata (L.) Blanco) rootstock planted in 2003. In Trial II, the experiments were performed with 12-year-old Midsweet orange (Citrus sinensis (L.) Osbeck) on Carrizo citrange (Poncirus trifoliata [L.] Raf. $\times$ C. sinensis [L] Osbeck.) rootstock planted in 2004. The two groves were established on well-drained Astatula fine sand soil (Typic Quartzipsamment). The orchard was naturally infected by Las with an HLB incidence of $>95 \%$. All trees received standard commercial care including regular irrigation, fertilization, and pest management practices which continued throughout the trial. One week prior to the start of the trial, a field survey was performed to determine HLB severity on individual trees based on visual assessment using the method described by Gottwald et al. (2007). Briefly, to assess disease severity, each tree was divided into eight sections, i.e., an upper and lower hemisphere with each hemisphere subdivided into four equal quadrants. Sections were scored individually on a 0 to 5 scale, indicative of the proportion of limbs expressing symptoms of HLB, and summed, providing a severity rating of 0 to 40 for each tree. All HLB-affected trees were classified into three categories based on disease severity. Briefly, category 1 trees had a disease severity index of 0 to 28 . Category 1 trees yielded sufficient, quality fruit ensuring them to be viable production units. Category 2 trees had a disease severity index of 28 to 36 . Category 2 trees yielded few, if any quality fruit. Category 3 trees had a disease severity index of 36 to 40 . Category 3 trees were moribund and thus had no economic value. Trees from the category 1 group (symptoms of HLB in $<30 \%$ of the canopy, a disease severity index of $<15$ ) were selected for the trials. Four days prior to treatment application, all selected trees were confirmed to be HLB positive and Las titers were determined using qPCR (Trivedi et al. 2009). The experiment was a randomized complete block design with eight treatments in the two trials. In Trial I, each treatment consisted of nine trees divided into three blocks of three contiguous trees each. In Trial II, each treatment consisted of 12 trees divided into three blocks of four contiguous trees each. 
Plant defense inducers, nitrogen fertilizer, and compost. All the components of each treatment (except the compost) were applied by foliar spray using a power-pumped handgun sprayer until runoff to ensure complete coverage. Spray treatments were applied every 3 to 4 months when new flush was present, starting with the spring flush in late February 2014 (Trial I) and 2015 (Trial II). Compost was applied to the soil once per year in February. Individual treatments were applied to the various plots as follows:

Trial I: T1 = water spray as control (WSC); T2 = compost; T3 = $\mathrm{Phi}+$ nitrogen fertilizer $(\mathrm{Phi}-\mathrm{N}) ; \mathrm{T} 4=\mathrm{Phi}-\mathrm{N}+$ compost $\mathrm{T} 5=\mathrm{BABA}+$ ascorbic acid (AA); T6 $=\mathrm{BABA}+\mathrm{AA}+\mathrm{Phi}-\mathrm{N} ; \mathrm{T} 7=\mathrm{BABA}+\mathrm{AA}+$ compost; and $\mathrm{T} 8=\mathrm{BABA}+\mathrm{AA}+\mathrm{Phi}-\mathrm{N}+$ compost.

Trial II: T1 = WSC; T2 = compost; $33=\mathrm{Phi}+$ Phi-N; T4 $=$ Phi-N + compost T5 $=\mathrm{BABA}+\mathrm{AA}+\mathrm{SA} ; \mathrm{T} 6=\mathrm{BABA}+\mathrm{AA}+\mathrm{SA}+\mathrm{Phi}-\mathrm{N}$; $\mathrm{T} 7=\mathrm{BABA}+\mathrm{AA}+\mathrm{SA}+$ compost and $\mathrm{T} 8=\mathrm{BABA}+\mathrm{AA}+\mathrm{SA}+\mathrm{Phi}-$ $\mathrm{N}+$ compost.

The chemicals BABA, AA, and SA were purchased from Fisher Scientific (Pittsburgh, PA). In Trial I, BABA and AA were applied at the concentration of $0.15 \mathrm{mM}$. In Trial II, BABA, AA, and SA were applied at the concentration of $0.5 \mathrm{mM}$. The Phi + nitrogen fertilizer (Phi-N) treatment consisted of a liquid form of potassium $(\mathrm{K})$ phosphite containing 56\% mono- and dipotassium salts of phosphorous acid polymers (K-Phite, Plant Food Systems, Zellwood, FL) (4.7 liters/ha) plus $0.5 \%$ urea (46-0-0 N-P-K, The Andersons, Maumee, OH). The compost used was Black Kow manure (0.5-0.5-0.5 N-P-K and beneficial microbes, Black Kow, Black Gold Compost Company, Oxford, FL). The compost was applied to the soil by distributing it around the trees in a circle $60 \mathrm{~cm}$ from the trunk at a rate of $45.4 \mathrm{~kg}$ for each tree (approximately 2.5 tons/ha) and covering it with soil.

HLB assessment, Las populations, and fruit yield, and quality measurements. HLB disease severity and the Las bacterial titer in treated trees were assessed every 6 months after initial application. Visual assessments of disease severity were performed using the method described by Gottwald et al. (2007). The disease severity data from individual evaluations from the eight individual canopy assessments for each tree were combined into a single value that was expressed as the standardized area under the disease progress stairs (sAUDPS) according to the method developed by Simko and Piepho (2012). The sAUDPS approach is an optimized estimation of disease progress with the area under the disease progress curve (AUDPC), giving a weight closer to optimal for the first and last

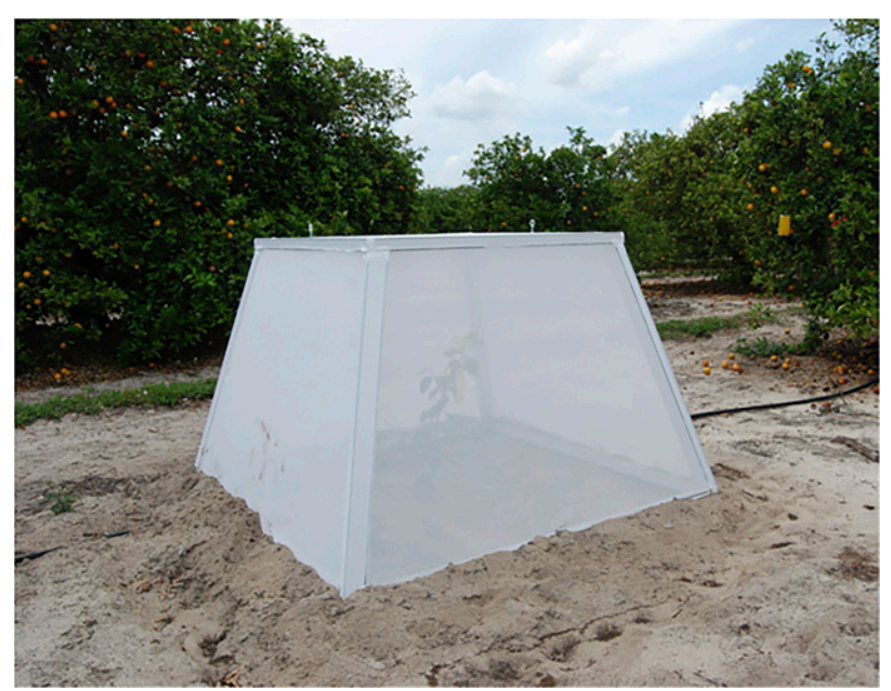

Fig. 1. The tree protectors used in the field trials. The protector design comprises a metal frame and psyllid proof 80 -mesh high-density polyethylene screen. The dimensions are $183 \times 183 \times 122 \mathrm{~cm}($ length $\times$ width $\times$ height $)$ The base is a flat rectangle $(5.1 \mathrm{~cm}$ wide and $5.1 \mathrm{~cm}$ thick $)$ with four holes distributed evenly on each side. Metal nails $(30.5 \mathrm{~cm}$ long) were used to fix the protector to the ground via the holes in the frame. observations. Leaf samples (16 leaves) were collected from the north, south, east, and west of individual trees (four leaves for each direction) for Las titer assays. The Las bacterial titer in leaf samples was determined by qPCR assays as described by Li et al. (2016). Change in Las titer was calculated after two or more sample collections:

\% Change in Las titer $=$
$\left(\frac{\text { mean titer after treatment }- \text { mean titer prior to treatment }}{\text { mean titer prior to treatment }}\right) \times 100$

Yield and fruit quality parameter measurements were conducted using previously described methods (Li et al. 2016). Fruit weight was recorded for individual trees and an 8-kg composite fruit sample was collected from each tree for quality analysis according to standard methods (Gottwald et al. 2012). Juice content and fruit acidity were expressed as percentage juice and percentage citric acid. Total soluble solids were expressed as fruit brix, a measure of sugar content in fruit, and were calculated as weight (g) of sugar in $100 \mathrm{~g}$ of juice. Fruit brix and acidity ratio were calculated accordingly.

Evaluation of the effect of thermotherapy treatments on citrus HLB of category 2 trees with severe infection. Three trials were conducted independently in a grove at the Citrus Research and Education Center (CREC) in Lake Alfred, Florida (Trial III), and in two commercial groves in Auburndale, Florida (Trial IV and V) from 2015 to 2017. In Trial III and Trial IV, the experiments were conducted with 10-year-old Hamlin sweet orange on Swingle citrumelo (C. paradisi Macf. 'Duncan' grapefruit $\times$ Poncirus trifoliata (L.) Raf.) rootstock planted in 2005. In Trial V, the experiments were conducted with 12-year-old Valencia sweet orange on Swingle citrumelo rootstock planted in 2003. All the trees received standard commercial orchard management. One-week prior to the start of each trial, a field survey was performed and all HLB-affected trees were classified into three categories based on disease severity as described above. Only the category 2 trees having severe symptoms of HLB and limited fruit production were selected. These trees were randomly distributed in the groves and consequently the experiment was a completely randomized design for all the three trials.

The thermotherapy treatments were applied using a mobile heat treatment system developed by Al-Jumaili and Ehsani (2015). The system consisted of an enclosure that covered the tree which was attached to a hauling truck with a portable steam generator, a water tank, a water supply pump, and an electric generator. Treatments were applied once a year in the summer (July) of 2015 and 2016. The trees were steamed at $55^{\circ} \mathrm{C}$ for $2 \mathrm{~min}$. In each of the three groves approximately 20 trees were treated, with 10 untreated trees serving as controls (20 trees were treated in Trial III; 24 in Trial IV, and 17 in Trial V). After heat treatment, HLB disease severity and Las bacterial titer was assessed in 10 randomly selected treated trees and the 10 untreated control trees in each trial as described above at 7, 28, 90, 180 , and 270 days after treatment, respectively. Yield and fruit quality parameters were measured at harvest as described above.

Evaluation of the effect of tree protectors protecting new citrus plantings from ACP/HLB after replanting. Field sites and experiment setup. Three trials were conducted independently in the same groves as used for the thermotherapy experiments described above. In this case, only the trees falling in category 3 exhibiting the most severe and advanced symptoms (i.e., dying) were selected. In the three groves, all the category 3 trees were removed and replanted with HLB-free, 8-month-old Hamlin (Trial VI and VII) or Valencia (Trial VIII) sweet orange (C. sinensis L. Osbeck) on Carrizo citrange rootstock obtained from a commercial citrus nursery in central Florida in March of 2015. All standard operating procedures for soil bed preparation, irrigation, fertilization, and pest control were followed during the replanting process. Immediately after planting, the replants were covered with tree protectors designed by the authors (Fig. 1). The tree protectors 
used in this study are conceptually similar to the CUPS previously described (Schumann and Singerman 2016). The tree protectors were self-supported and covered the trees with mesh screen to exclude ACP. The protectors were fixed to the ground using metal nails. In total, 30 trees were covered in Trial VI, 40 trees in Trial VII, and 20 trees in Trial VIII. The experiment was a completely randomized design for all three trials as the trees were randomly distributed in the groves. A total of 10 of the covered trees in each trial were randomly selected to evaluate the effect of tree protectors, with 10 replants that were left uncovered evaluated as controls. All the replants received standard commercial management.

Evaluation of effect of protectors excluding ACP/HLB. Yellow sticky card traps were used to monitor populations of ACP. The traps were replaced monthly in uncovered control trees and in trees under and around the tree protectors in all three trials to monitor whether psyllids could penetrate the tree screen. qPCR assays were performed to determine the Las status of covered and uncovered control replants every 3 months after planting. Percentage of replants that were qPCR positive for Las was determined for each trial.

Evaluation of replanted tree growth within the protectors. Tree growth was evaluated by estimating trunk diameter, tree height $(\mathrm{TH})$, and canopy volume (CV) on both covered and uncovered control replant trees every 3 months after planting. Digital calipers (Fowler, Newton, MA) were used to take two measurements of trunk diameter (north-south and east-west orientation) at $7.5 \mathrm{~cm}$ above the graft union. To ensure the same location was measured each time, it was marked with white latex paint for future measurements. The TH above the ground was measured with a tape measure from the soil surface to the apical point of the plant. $\mathrm{CV}$ was estimated by taking the average of three independent measurements of the diameter of the canopy at different directions. The CV was estimated as follows: $V=(2 / 3) \times \pi \times h \times(d / 2)^{2}$, where $h$ is the TH and $d$ is the average diameter of the tree.

Measurements of air temperature, relative humidity $(\mathrm{RH})$, and soil moisture within and outside the protectors. "Watchdog" Data Loggers (Spectrum Technologies, Aurora, IL) were used to monitor the air temperature (Tm) and $\mathrm{RH}$ inside and outside the protectors in both Trial VI and Trial VIII. Three pairs of Data Loggers were placed both inside and outside the protectors at three different locations in each trial. Air Tm and RH data were collected monthly until the protectors were removed due to tree size. Five covered trees in Trial VI were randomly selected for soil moisture assays at four different times during dry (no rain within 13 days prior to the test) and wet (immediately after heavy rain) conditions, respectively. The testing dates for dry conditions were 19 January, 11 February, 14 March, and 13 April 2016, and for wet conditions were 4 January, 29 January, 30 March, and 5 May 2016. The measurement was performed at a depth of $20 \mathrm{~cm}$ using a HydroSense (Campbell Scientific Australia, Garbutt, QLD, Australia) soil moisture probe. Five uncovered trees were measured as a control. For each tree, the soil moisture was measured at four different sites, at $10 \mathrm{~cm}$ east, west, south, and north of the trunk.

Statistical analysis. All statistical analyses were performed using SAS V9.3 (SAS Institute Inc., Cary, NC). The data were first tested for normality and homogeneity of variance using the MODEL procedure in SAS. As the Las titer data were nonnormally distributed, they were $\log _{10}$ transformed to satisfy assumptions of normality and homoscedasticity. A one-way analysis of variance (ANOVA) was performed to determine any differences among treatments for change in Las titer, sAUDPS, fruit yield and juice quality parameters for the 'plant defense inducers, nutrients, and compost' trials (Trials I and II). Multiple comparisons were made using Tukey's HSD test $(\alpha=0.05)$. A Student's two-tailed $t$ test was performed to explore differences between treatments for change in Las titer and sAUDPS in the 'Thermotherapy' trials, and between ACP populations, percentage of replantings that were qPCR positive for Las, growth performance traits, and soil moisture in the 'Evaluation of the effect of tree protectors' trials (Trials III, IV, V, VI, VII, and VIII). In the tree protector trials (Trials VI, VII, and VIII), the three experiments were analyzed both independently and combined. The trials had the same experiment design and sample timing for each treatment, and thus the data from the three trials were amenable to combining to increase sample size for each treatment group to improve the power of the statistical analysis.

\section{RESULTS}

Effect of plant defense inducers, nitrogen fertilizer, and compost treatments on HLB disease progression. Over the 2-year and 3-year duration of both Trial I and Trial II, the severity of HLB increased. However, the plant defense inducers BABA + AA with or without SA, alone or combined with Phi-N, compost, or Phi$\mathrm{N}$ and compost slowed the increase in HLB symptom severity $\left(F_{7,64}=\right.$ $7.46, P<0.0001$ for Trial I; $F_{7,88}=9.25, P<0.0001$ for Trial II), and reduced Las populations $\left(F_{7,64}=8.26, P<0.0001\right.$ for Trial I $; F_{7,88}=$ $9.57, P<0.0001$ for Trial II) compared with the WSC (Figs. 2 and 3 ).

In Trial I, water sprayed trees had a fivefold increase in Las titer, but the BABA + AA + Phi-N + compost treatment had only a 3.5fold increase in Las titer, and $17.5 \%$ less severe symptoms (reduction in sAUDPS) at the end of the experiment (Fig. 2A and B). Control achieved by applying BABA + AA, BABA + AA + Phi$\mathrm{N}$, or $\mathrm{BABA}+\mathrm{AA}+$ compost was not statistically different from that using BABA + AA + Phi-N + compost. Addition of the Phi-N, compost, or the combination of Phi-N and compost with BABA + AA did not result in a lower Las titer or reduce progress of symptoms of HLB compared with BABA + AA alone. Compost or Phi-N, alone or in combination, did not affect Las titer or progress of HLB compared with the WSC.

In Trial II, while the control trees (WSC) had a threefold increase in Las titer, the BABA + AA + SA + Phi-N + compost treatment had only a twofold increase and had $18.6 \%$ less severe symptoms of HLB (reduction in sAUDPS) compared with the WSC (Fig. 3A and B). Control using BABA + AA + SA, BABA + AA + SA + Phi-N, or $\mathrm{BABA}+\mathrm{AA}+\mathrm{SA}+$ compost was not significantly different to that using BABA + AA + SA + Phi-N + compost treatment. Addition of Phi-N, compost, or the combination of Phi-N and compost with the plant defense inducer BABA + AA + SA did not result in lower Las titer or reduce progress of symptoms of HLB compared with plant defense inducers alone. Compost or Phi-N, alone or in combination, did not reduce Las titer or progress of HLB compared with the WSC.

Effect of plant defense inducers, nitrogen fertilizer and compost on fruit yield and quality. In both trials fruit yield of control trees declined but was constant on trees treated with the plant defense inducers BABA + AA with or without SA alone or combined with Phi-N, compost, or Phi-N and compost (Fig. 4). Although there was no effect of treatment on yield in 2015 for Trial I $\left(F_{7,64}=1.25, P=0.27\right)$ or in 2016 for Trial II $\left(F_{7,88}=1.64, P=0.24\right)$, by the end of the experiments the plant defense inducers BABA + AA with or without SA alone or combined with Phi-N, compost, or Phi-N and compost significantly improved fruit yield compared with the WSC $\left(F_{7,64}=11.25, P=0.00054\right.$ for Trial I; $F_{7,88}=13.12$, $P=0.00028$ for Trial II) (Tables 1 and 2). At the end of Trial I, the $\mathrm{BABA}+\mathrm{AA}$ treatment resulted in a higher fruit yield compared with the WSC (33.5 versus $25.7 \mathrm{Kg} /$ tree, respectively), and was comparable to the treatments integrating BABA + AA with Phi-N or compost, but was different to BABA + AA combined with Phi-N and compost. The combination of the Phi-N and compost with $\mathrm{BABA}+\mathrm{AA}$ resulted in higher fruit yield compared with BABA + AA alone (40.6 versus $33.5 \mathrm{~kg} /$ tree, respectively). At the end of Trial II, the BABA + AA + SA treatment resulted in a higher fruit yield compared with the WSC (40.6 versus $33.3 \mathrm{~kg} /$ tree, respectively). Improvement in fruit yield due to the $\mathrm{BABA}+\mathrm{AA}+\mathrm{SA}$ treatment was comparable to the treatments integrating $\mathrm{BABA}+\mathrm{AA}+\mathrm{SA}$ with Phi-N or compost, but not to the treatment of BABA + AA $+\mathrm{SA}$ 
combined with Phi-N and compost. The combination of Phi-N and compost with $\mathrm{BABA}+\mathrm{AA}+\mathrm{SA}$ resulted in higher fruit yield compared with BABA + AA + SA alone (47.9 versus $33.3 \mathrm{~kg} /$ tree, respectively).

In both trials all fruit quality parameters were generally within normal ranges, and there were no significant differences between any treatments and the WSC for any of the variables measured (Tables 1 and 2).
Effect of thermotherapy on HLB disease progression. In all three trials, within 90 days posttreatment (DPT) the Las titer in the treated trees was reduced or had increased less compared with the untreated control $(P \leq 0.009$ for Trial III; $P \leq 0.001$ for Trial IV; $P \leq 0.004$ for Trial V; Student's $t$ test, two-tailed). This indicates a repressive effect of heat on Las (Fig. 5). For example, in year 1, Trial III, the Las titer in the treated trees was reduced by $75 \%$ at 28 DPT and increased $45 \%$ at 90 DPT, while Las titer in untreated control
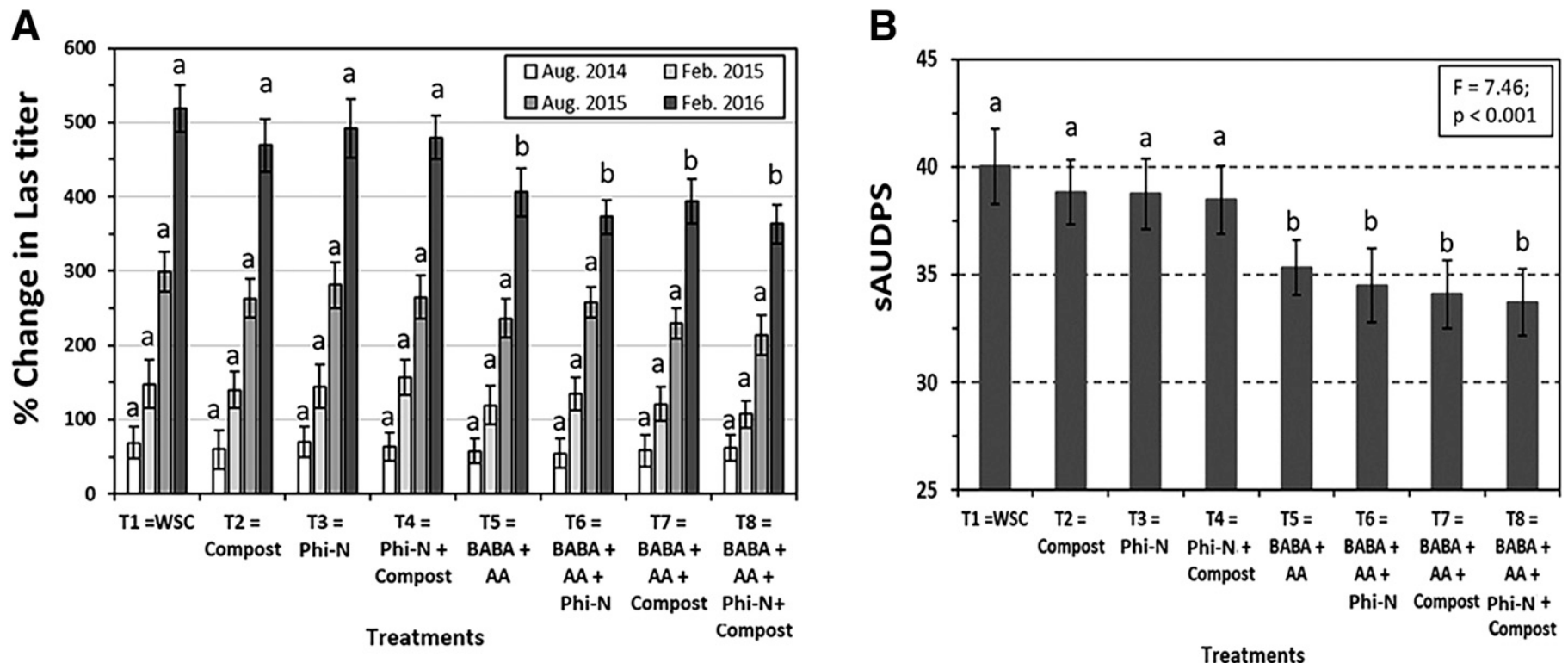

Fig. 2. Effect of plant defense inducers, nutrients, and compost on development of symptoms of Huanglongbing (HLB) in Trial I. A, Change in titer of 'Candidatus Liberibacter asiaticus' (Las) in leaf samples of Murcott orange trees for each treatment. BABA + AA: plant defense inducers; Phi-N: Potassium phosphite + nitrogen fertilizer. Las titers were estimated using quantitative real-time polymerase chain reaction assays. Treatment effect was expressed as follows: \% Change in Las titer $=[($ mean titer after treatment - mean titer prior to treatment $) /$ mean titer prior to treatment $] \times 100$. Statistical analysis was performed with a one-way analysis of variance and Tukey's HSD test $(\alpha=0.05)$ for means comparisons. Means at the same sampling time with different letters $(a$ or $b)$ are significantly different $\left(F_{7,64}=8.26, P<0.0001\right.$ in February 2016, $n=9$ replicate trees per treatment); data are shown as mean \pm standard deviation. B, Severity of HLB expressed as the standardized area under the disease progress stairs (sAUDPS) for different treatments over time. Statistical analysis as in A. Means indicated by different letters $(\mathrm{a}$ and $\mathrm{b})$ are significantly different $\left(F_{7,64}=7.46, P<0.0001\right)$.
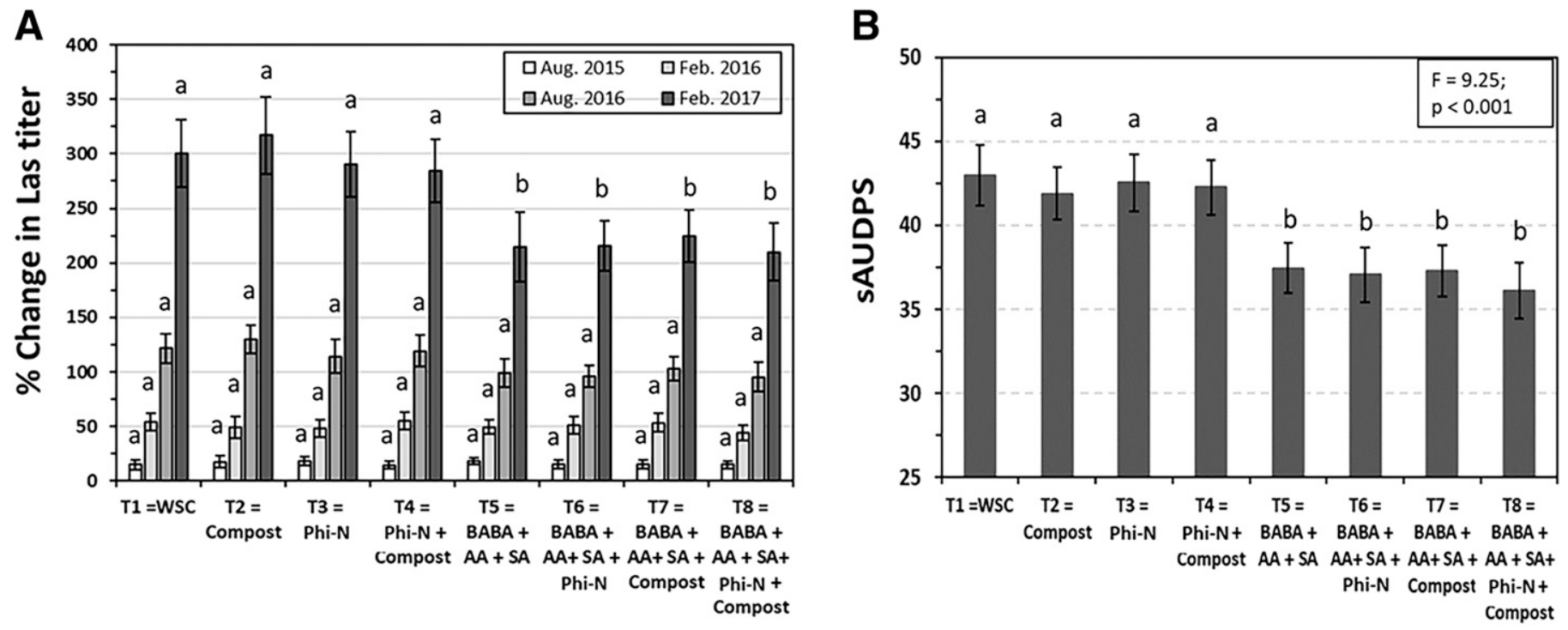

Fig. 3. Effect of plant defense inducers, nutrients, and compost on citrus Huanglongbing (HLB) disease progression in Trial II. A, Change in titer of 'Candidatus Liberibacter asiaticus' (Las) in leaf samples of Midsweet orange trees under different treatments. BABA + AA + SA: plant defense inducers; Phi-N: Potassium phosphite + nitrogen fertilizer. Las titers were estimated using quantitative real-time polymerase chain reaction assays. Treatment effect was expressed as follows: $\%$ Change in Las titer $=[$ (mean titer after treatment - mean titer prior to treatment $) /$ mean titer prior to treatment $] \times 100$. Statistical analysis was performed with a one-way analysis of variance and Tukey's HSD test $(\alpha=0.05)$ for means comparisons. Means at the same sampling time with different letters $(a$ or b) are significantly different $\left(F_{7,88}=9.57, P<0.0001\right.$ for February 2017, $n=12$ replicate trees per treatment $)$; data are shown as mean \pm standard deviation. B, Severity of HLB expressed as the standardized area under the disease progress stairs (sAUDPS) for different treatments over time. Statistical analysis as in A. Means indicated by different letters (a and $\mathrm{b})$ are significantly different $\left(F_{7,88}=9.25, P<0.0001\right)$. 
trees increased 25 and $80 \%$ at 28 and 90 DPT, respectively. In Trial IV, the Las titer in the treated trees was reduced by $50 \%$ and $48 \%$ at 28 and 90 DPT, while Las titer in untreated control trees increased 18 and $65 \%$ at 28 and 90 DPT, respectively. In Trial V, the Las titer in the treated trees was reduced by $46 \%$ and $8 \%$ at 28 and 90 DPT, whereas Las titer in untreated control trees increased 35 and $62.5 \%$ at 28 and 90 DPT, respectively. However, in all three trials, 6 months after the thermotherapy treatment the Las titer in the treated trees recovered to levels similar to those in the untreated control (Fig. 5). Consistent with the transient reduction in Las titer, the severity of HLB in treated trees was reduced compared with the untreated control trees (Fig. 6).

The tree protectors prevented new citrus plantings from ACP and Las infection. In all three trials no ACPs were observed on the replants that were covered by tree protectors, whereas ACPs were observed consistently on both control (uncovered) and surrounding trees (Fig. 7). The results from both the individual experiments and the combined data were similar (Table 3). Covered trees did not develop symptoms of HLB, whereas symptoms (vein yellowing and leaf chlorosis) were observed in approximately $80 \%$ of the unprotected control trees in each trial. One month after protectors were removed from the covered trees, 55, 40, and $40 \%$ of the unprotected trees were confirmed as Las positive in Trial VI, Trial VII, and Trial VIII, respectively, but all protected trees were determined to be Las negative. At 5 months after removal of the protectors, 80,60 , and $80 \%$ of unprotected trees were Las positive in Trial VI, Trial VII, and Trial VIII, respectively, while 5 to $10 \%$ of the protected trees were determined to be Las positive. At 12 months after protectors were removed, 100, 95, and $100 \%$ of control trees were Las positive in Trial VI, Trial VII, and Trial VIII, respectively, and 20 to $40 \%$ of the protected trees in each trial were determined to be Las positive, which was significantly less compared with the unprotected control.

Effect of protectors on growth of replants. In all three trials, starting at 9 months after replanting, protected trees were taller and had larger canopy volume compared with control trees
A

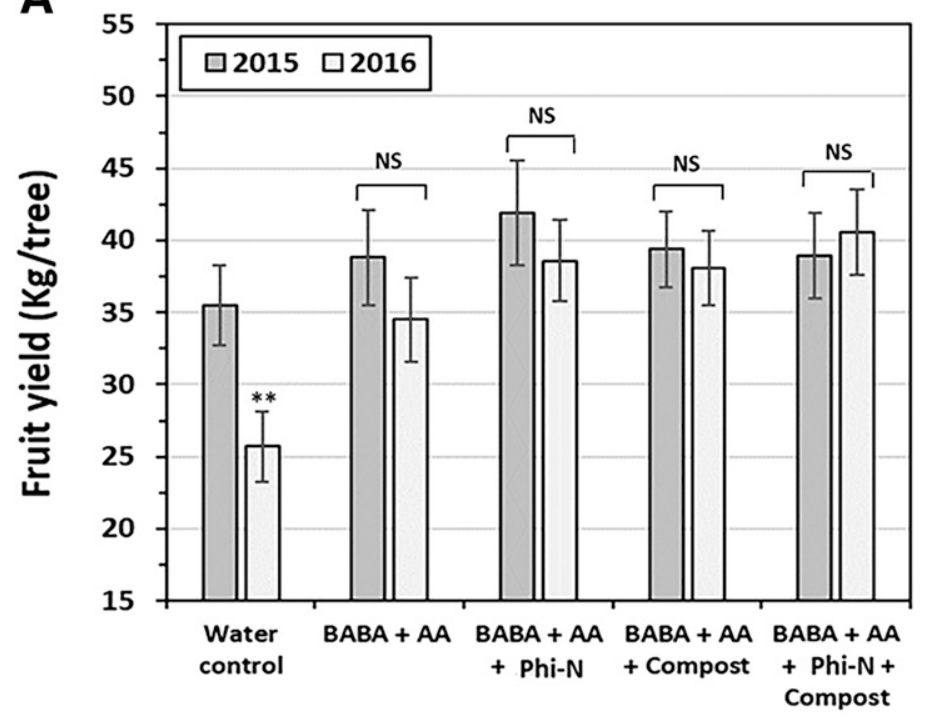

B

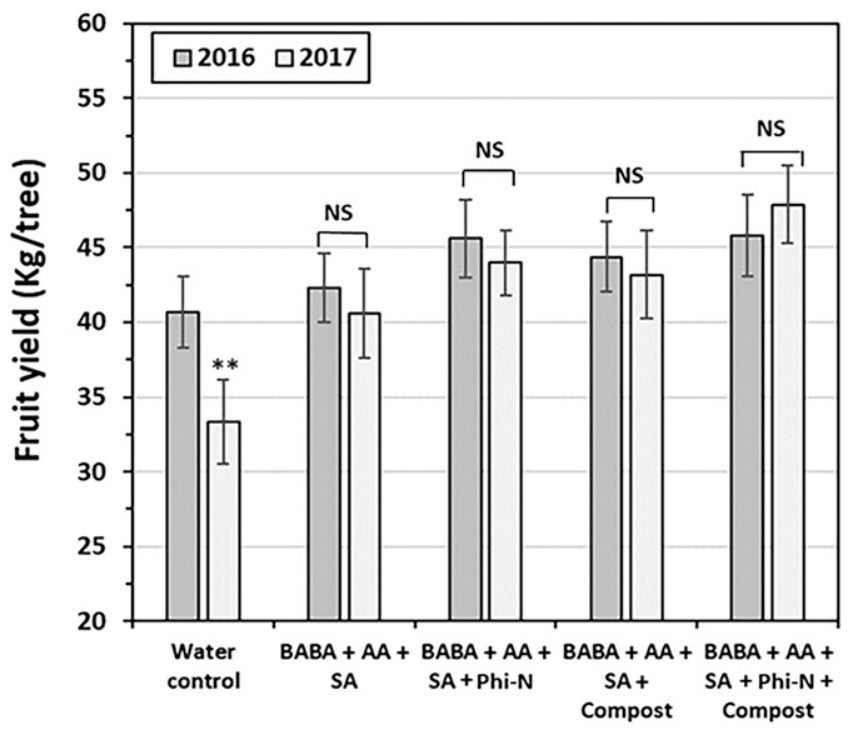

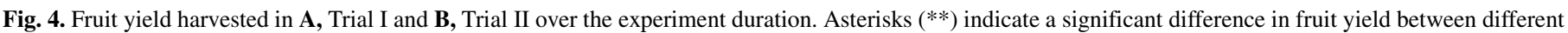

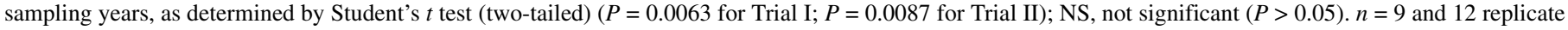
trees for Trial I and Trial II, respectively. BABA + AA or BABA + AA + SA: plant defense inducers; Phi-N: Potassium phosphite + nitrogen fertilizer.

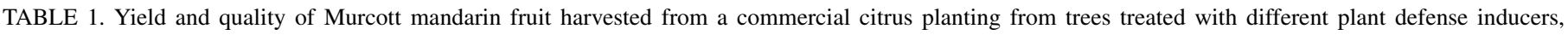
nutrients, and compost treatments to suppress Huanglongbing in Lake Wales, Florida in February 2015 and February 2016 (Trial I) ${ }^{\mathrm{y}}$

\begin{tabular}{|c|c|c|c|c|c|c|c|c|c|c|}
\hline \multirow[b]{3}{*}{ Treatment $^{\mathrm{z}}$} & \multirow{2}{*}{\multicolumn{2}{|c|}{ Yield (kg/tree) }} & \multicolumn{8}{|c|}{ Quality } \\
\hline & & & \multicolumn{2}{|c|}{$\begin{array}{l}\text { Percent juice } \\
\text { content }\end{array}$} & \multicolumn{2}{|c|}{ Fruit brix } & \multicolumn{2}{|c|}{ Fruit acidity } & \multicolumn{2}{|c|}{$\begin{array}{c}\text { Fruit brix acidity } \\
\text { ratio }\end{array}$} \\
\hline & 2015 & 2016 & 2015 & 2016 & 2015 & 2016 & 2015 & 2016 & 2015 & 2016 \\
\hline $\mathrm{T} 1$ & $35.5 \mathrm{a}$ & $25.7 \mathrm{c}$ & $53.5 \mathrm{a}$ & $51.5 \mathrm{a}$ & $10.6 \mathrm{a}$ & $11.1 \mathrm{a}$ & $0.57 \mathrm{a}$ & $0.59 \mathrm{a}$ & $18.5 \mathrm{a}$ & $18.8 \mathrm{a}$ \\
\hline $\mathrm{T} 2$ & $40.9 \mathrm{a}$ & $26.1 \mathrm{c}$ & $57.1 \mathrm{a}$ & $53.9 \mathrm{a}$ & $10.8 \mathrm{a}$ & $10.4 \mathrm{a}$ & $0.59 \mathrm{a}$ & $0.56 \mathrm{a}$ & $18.2 \mathrm{a}$ & $18.5 \mathrm{a}$ \\
\hline $\mathrm{T} 3$ & $33.6 \mathrm{a}$ & $24.2 \mathrm{c}$ & $54.1 \mathrm{a}$ & $52.7 \mathrm{a}$ & $11.3 \mathrm{a}$ & $10.7 \mathrm{a}$ & $0.56 \mathrm{a}$ & $0.59 \mathrm{a}$ & $20.1 \mathrm{a}$ & $18.1 \mathrm{a}$ \\
\hline $\mathrm{T} 4$ & $36.1 \mathrm{a}$ & $25.3 \mathrm{c}$ & $56.5 \mathrm{a}$ & $54.3 \mathrm{a}$ & $10.6 \mathrm{a}$ & $10.8 \mathrm{a}$ & $0.54 \mathrm{a}$ & $0.60 \mathrm{a}$ & $19.5 \mathrm{a}$ & $18.0 \mathrm{a}$ \\
\hline T5 & $39.8 \mathrm{a}$ & $33.5 \mathrm{~b}$ & $60.3 \mathrm{a}$ & $53.5 \mathrm{a}$ & $10.8 \mathrm{a}$ & $10.4 \mathrm{a}$ & $0.56 \mathrm{a}$ & $0.59 \mathrm{a}$ & $19.3 \mathrm{a}$ & $17.6 \mathrm{a}$ \\
\hline T6 & $41.9 \mathrm{a}$ & $36.8 \mathrm{ab}$ & $59.7 \mathrm{a}$ & $56.2 \mathrm{a}$ & $10.7 \mathrm{a}$ & $11.3 \mathrm{a}$ & $0.55 \mathrm{a}$ & $0.59 \mathrm{a}$ & $19.5 \mathrm{a}$ & $19.1 \mathrm{a}$ \\
\hline $\mathrm{T} 7$ & $39.4 \mathrm{a}$ & $38.1 \mathrm{ab}$ & $55.4 \mathrm{a}$ & $52.9 \mathrm{a}$ & $11.2 \mathrm{a}$ & $10.5 \mathrm{a}$ & $0.57 \mathrm{a}$ & $0.60 \mathrm{a}$ & $19.7 \mathrm{a}$ & $17.5 \mathrm{a}$ \\
\hline $\mathrm{T} 8$ & $38.9 \mathrm{a}$ & $40.6 \mathrm{a}$ & $56.1 \mathrm{a}$ & $54.7 \mathrm{a}$ & $11.1 \mathrm{a}$ & $10.7 \mathrm{a}$ & $0.60 \mathrm{a}$ & $0.56 \mathrm{a}$ & $18.4 \mathrm{a}$ & $19.1 \mathrm{a}$ \\
\hline$F_{7,64}$ & 1.25 & 11.25 & 1.77 & 1.22 & 1.12 & 1.36 & 1.52 & 1.16 & 1.38 & 1.61 \\
\hline$P$ & 0.27 & 0.00054 & 0.31 & 0.23 & 0.35 & 0.22 & 0.17 & 0.26 & 0.23 & 0.36 \\
\hline
\end{tabular}

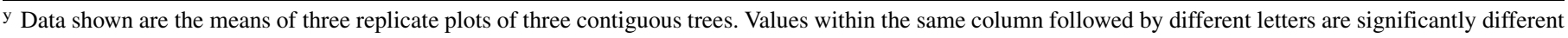
based on a post hoc means separation using Tukey's HSD test $(\alpha=0.05)$.

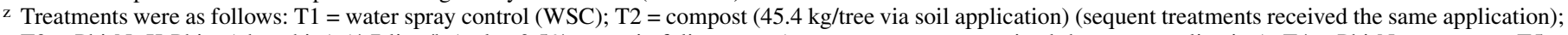
$\mathrm{T} 3$ = Phi-N: K-Phite (phosphite) $(4.7$ liter/ha) plus $0.5 \%$ urea via foliar spray (sequent treatments received the same application); $\mathrm{T} 4=\mathrm{Phi}-\mathrm{N}+\mathrm{compost}$; T5 = $\mathrm{BABA}+\mathrm{AA}$; Both are applied at $0.15 \mathrm{mM}$ via foliar spray (sequent treatments received the same application); $6=\mathrm{BABA}+\mathrm{AA}+\mathrm{Phi}-\mathrm{N} ; \mathrm{T} 7=\mathrm{BABA}+\mathrm{AA}+$ compost; and $\mathrm{T} 8=\mathrm{BABA}+\mathrm{AA}+\mathrm{Phi}-\mathrm{N}+$ compost. 
(data not shown). At the termination of the experiments when the protectors were removed, protected trees were significantly taller and had larger canopy volume compared with control trees (Table 4). For example, in Trial VI, the average tree height and canopy volume of protected trees was $136 \mathrm{~cm}$ and $4,526 \mathrm{~cm}^{3}$, respectively, while for the uncovered control trees they were $115 \mathrm{~cm}$ and $3,198 \mathrm{~cm}^{3}$, respectively. The results indicate that the protectors altered growing conditions, positively affecting young tree development. Both in hot (summer) and cool (winter) weather, slightly higher air Tm and lower RH was observed within the protector in both trials during the afternoon. The Tm inside the protector was 3 to $5^{\circ} \mathrm{C}$ higher compared with outside, whereas $\mathrm{RH}$ inside was 3 to $5 \%$ lower compared with outside in the afternoon from $12 \mathrm{p} . \mathrm{m}$. to 5 p.m., but only in the absence of rain (Supplementary Fig. S1). Higher soil moisture was maintained under the protector compared with bare ground during dry weather (no rain for $>13$ days) (Supplementary Fig. S2).

\section{DISCUSSION}

In this study, we tested different approaches to control HLB based on the severity of symptoms of HLB, which represents the degree of

TABLE 2. Yield and quality of orange fruit harvested from a field trial in mid-Florida from trees receiving different treatments of plant defense inducers, nutrients and compost to suppress citrus Huanglongbing in February 2016 and February 2017 (Trial II) ${ }^{\mathrm{y}}$

\begin{tabular}{|c|c|c|c|c|c|c|c|c|c|c|}
\hline \multirow[b]{3}{*}{ Treatment $^{z}$} & \multirow{2}{*}{\multicolumn{2}{|c|}{ Yield (kg/tree) }} & \multicolumn{8}{|c|}{ Quality } \\
\hline & & & \multicolumn{2}{|c|}{$\begin{array}{c}\text { Percent } \\
\text { juice content }\end{array}$} & \multicolumn{2}{|c|}{ Fruit brix } & \multicolumn{2}{|c|}{ Fruit acidity } & \multicolumn{2}{|c|}{$\begin{array}{l}\text { Fruit brix acidity } \\
\text { ratio }\end{array}$} \\
\hline & 2016 & 2017 & 2016 & 2017 & 2016 & 2017 & 2016 & 2017 & 2016 & 2017 \\
\hline $\mathrm{T} 1$ & $40.7 \mathrm{a}$ & $33.3 \mathrm{c}$ & $53.5 \mathrm{a}$ & $52.5 \mathrm{a}$ & $11.5 \mathrm{a}$ & $13.8 \mathrm{a}$ & $0.49 \mathrm{a}$ & $0.66 \mathrm{a}$ & $23.4 \mathrm{a}$ & $21.2 \mathrm{a}$ \\
\hline $\mathrm{T} 2$ & $42.9 \mathrm{a}$ & $34.2 \mathrm{c}$ & $55.6 \mathrm{a}$ & $53.6 \mathrm{a}$ & $12.2 \mathrm{a}$ & $14.4 \mathrm{a}$ & $0.50 \mathrm{a}$ & $0.63 \mathrm{a}$ & $24.4 \mathrm{a}$ & $22.9 \mathrm{a}$ \\
\hline T3 & $42.5 \mathrm{a}$ & $32.8 \mathrm{c}$ & $56.7 \mathrm{a}$ & $55.5 \mathrm{a}$ & $11.5 \mathrm{a}$ & $14.1 \mathrm{a}$ & $0.51 \mathrm{a}$ & $0.66 \mathrm{a}$ & $22.3 \mathrm{a}$ & $21.5 \mathrm{a}$ \\
\hline $\mathrm{T} 4$ & $40.5 \mathrm{a}$ & $33.4 \mathrm{c}$ & $57.7 \mathrm{a}$ & $54.4 \mathrm{a}$ & $12.5 \mathrm{a}$ & $13.6 \mathrm{a}$ & $0.55 \mathrm{a}$ & $0.65 \mathrm{a}$ & $22.7 \mathrm{a}$ & $20.9 \mathrm{a}$ \\
\hline $\mathrm{T} 7$ & $44.4 \mathrm{a}$ & $43.2 \mathrm{ab}$ & $57.4 \mathrm{a}$ & $54.5 \mathrm{a}$ & $12.1 \mathrm{a}$ & $13.5 \mathrm{a}$ & $0.57 \mathrm{a}$ & $0.61 \mathrm{a}$ & $21.2 \mathrm{a}$ & $22.1 \mathrm{a}$ \\
\hline $\mathrm{T} 8$ & $45.8 \mathrm{a}$ & $47.9 \mathrm{a}$ & $58.6 \mathrm{a}$ & $55.5 \mathrm{a}$ & $12.7 \mathrm{a}$ & $13.7 \mathrm{a}$ & $0.55 \mathrm{a}$ & $0.60 \mathrm{a}$ & $23.1 \mathrm{a}$ & $22.8 \mathrm{a}$ \\
\hline$F_{7,88}$ & 1.64 & 13.12 & 1.52 & 1.41 & 1.68 & 1.53 & 1.12 & 1.55 & 1.26 & 1.39 \\
\hline$P$ & 0.24 & 0.00028 & 0.22 & 0.37 & 0.21 & 0.26 & 0.28 & 0.21 & 0.19 & 0.25 \\
\hline
\end{tabular}

${ }^{y}$ Data shown are the means of three replicate plots of three contiguous trees. Values within the same column followed by different letters are significantly different based on a post hoc means separation using Tukey's HSD test $(\alpha=0.05)$.

$\mathrm{z}$ Treatments were as follows: T1 = water spray control (WSC); T2 = compost (45.4 kg/tree via soil application) (sequent treatments received the same application); T3 = Phi-N: K-Phite (phosphite) $(4.7$ liter/ha) plus $0.5 \%$ urea via foliar spray (sequent treatments received the same application); $44=\mathrm{Phi}-\mathrm{N}+$ compost; $\mathrm{T} 5=$ $\mathrm{BABA}+\mathrm{AA}$; Both are applied at $0.15 \mathrm{mM}$ via foliar spray (sequent treatments received the same application); $\mathrm{T} 6=\mathrm{BABA}+\mathrm{AA}+\mathrm{Phi}-\mathrm{N} ; \mathrm{T} 7=\mathrm{BABA}+\mathrm{AA}+$ compost; and $\mathrm{T} 8=\mathrm{BABA}+\mathrm{AA}+\mathrm{Phi}-\mathrm{N}+$ compost.

A
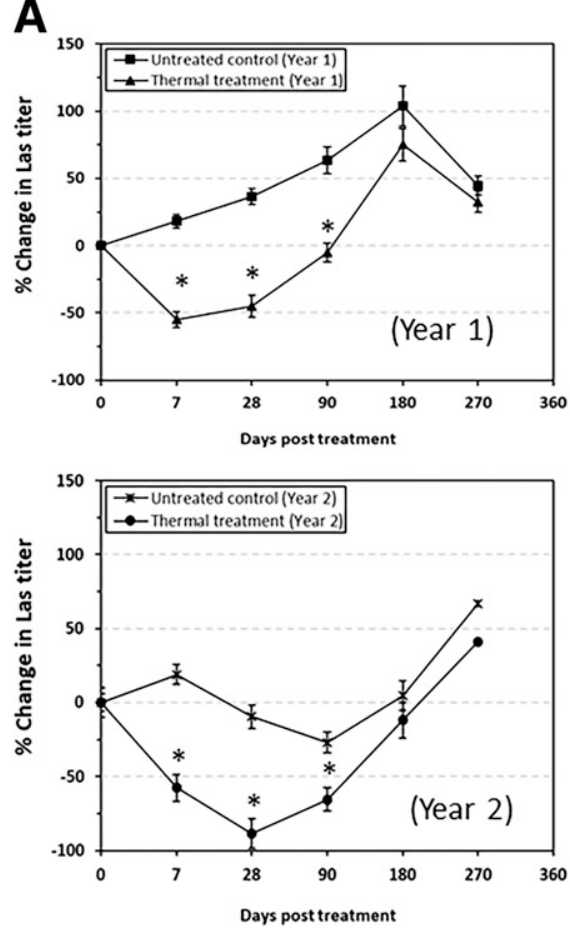

B
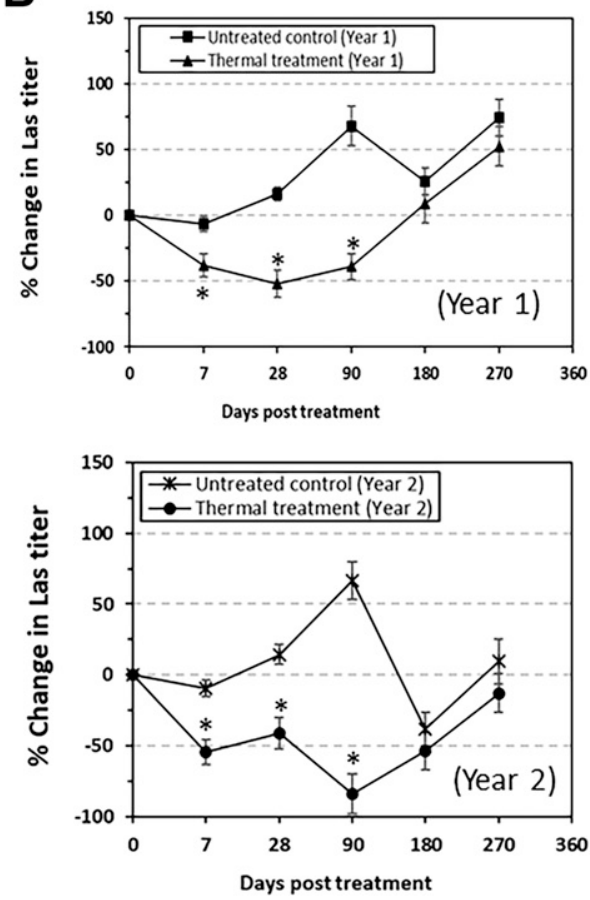

C
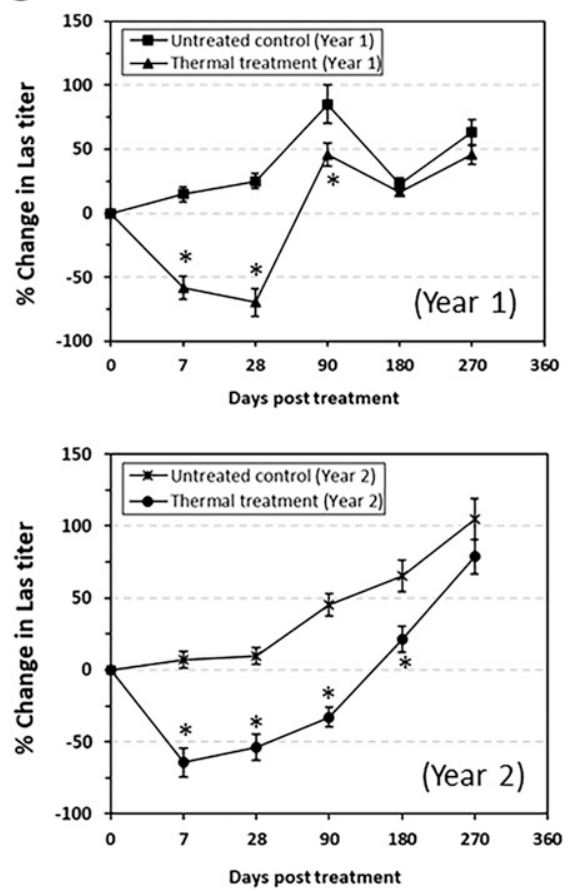

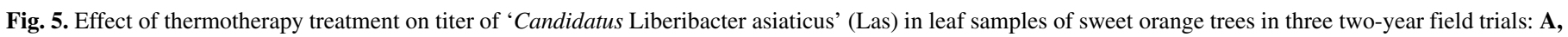

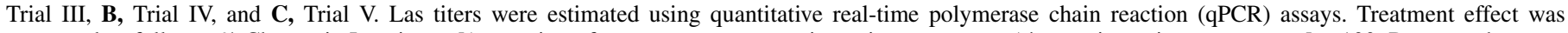

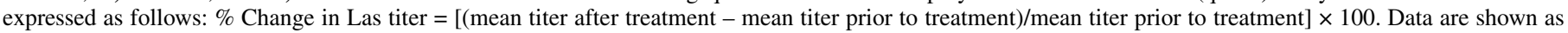

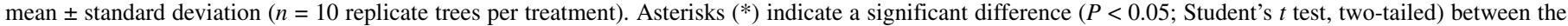
treatment and control. 
colonization of the tree by Las. Specifically, our results indicate an integrated approach consisting of protecting new plantings from psyllids and applying plant defense elicitors, nitrogen fertilizer, compost, and thermotherapy applied to mildly diseased trees may provide a practical approach for citrus growers to further combat HLB. Our findings indicated that this integrated approach slowed down the progress of HLB, maintained tree health and fruit yield of diseased trees during the testing period, and protected new plantings from infection by Las. Therefore, this approach may be useful and be further optimized and integrated into existing programs for control and management of citrus HLB in Florida and elsewhere.

Manipulating a plant's induced resistance mechanism for disease control is a sustainable approach to crop protection ( $\mathrm{Fu}$ and Dong 2013). Several studies have demonstrated that plant defense elicitors trigger plant defense against citrus HLB, although the efficacy varied greatly from inconsequential to moderate under field conditions (Gottwald et al. 2012; Hu et al. 2018; Li et al. 2016, 2017). However, it has been proposed that induced resistance could be costly, and adversely affect crop biomass and yield production owing to the metabolic competition between biological processes for plant vegetative growth, reproductive development, and the synthesis of defense-related compounds (Cipollini et al. 2003). This could be especially problematic under nitrogen-limiting conditions
(Heil et al. 2000). Thus, we surmise that a nitrogen supplement should be incorporated to avoid stressful conditions when treating HLB-infected citrus with plant defense inducers.

Previous field trials demonstrated effectiveness of BABA + ascorbic acid (AA) and SA in suppressing growth of Las and slowed progress of HLB in infected citrus trees (Hu et al. 2018; Li et al. 2016, 2017). The results obtained in this study are in agreement with results from those earlier studies. In both trials, $\mathrm{BABA}+\mathrm{AA}(+\mathrm{SA})$ combined with Phi-N, compost, or Phi-N and compost, or alone, significantly suppressed Las titer and slowed progress of HLB compared with the untreated control (Figs. 1 and $2)$. Additionally, the combination of BABA + AA (+SA), Phi-N, and compost was the most effective treatment in maintaining fruit yield, followed by BABA+AA $(+\mathrm{SA})+$ Phi-N, BABA + AA $(+\mathrm{SA})+$ compost, and BABA + AA (+SA) (Tables 1 and 2).

Phi-N alone or combined with compost was not effective in reducing titer of Las, slowing progress of HLB, or maintaining fruit yield relative to the WSC. Our results contrast with those from trunk-injected Phi. Trunk injection of Phi was reported to reduce titer of Las, slow progress of HLB, and improve fruit yield in HLBdiseased citrus trees (Hu et al. 2018). This difference might be due to application method and rate of Phi applied in the two studies. Hu et al. (2018) applied Phi at 0.9 to $1.0 \mathrm{~g} /$ tree with trunk injection.
A

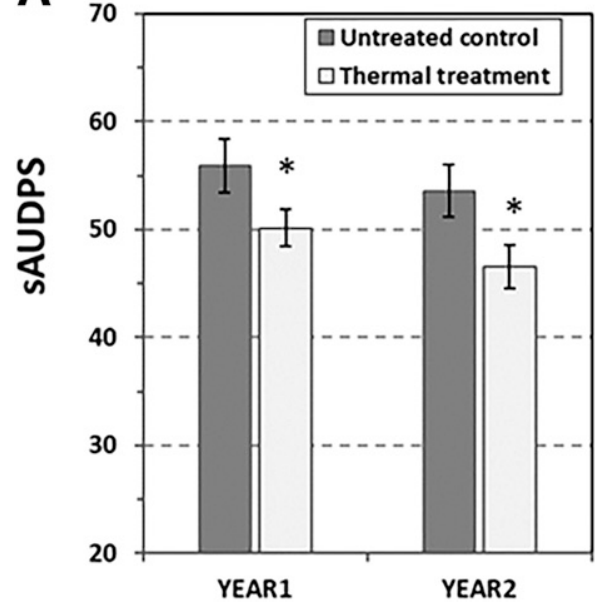

B

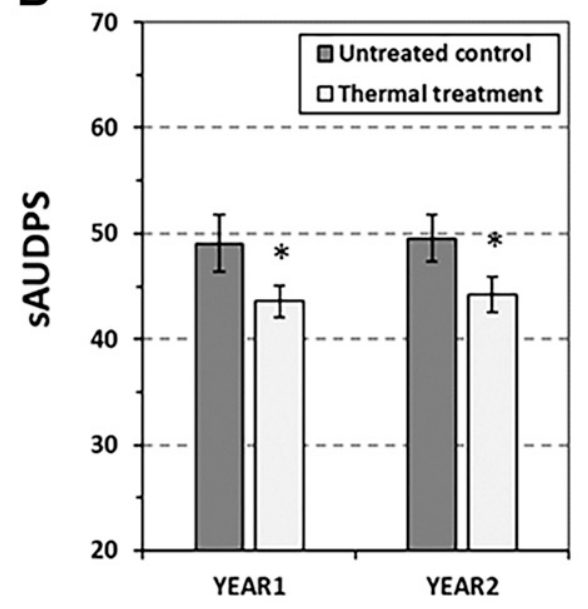

C

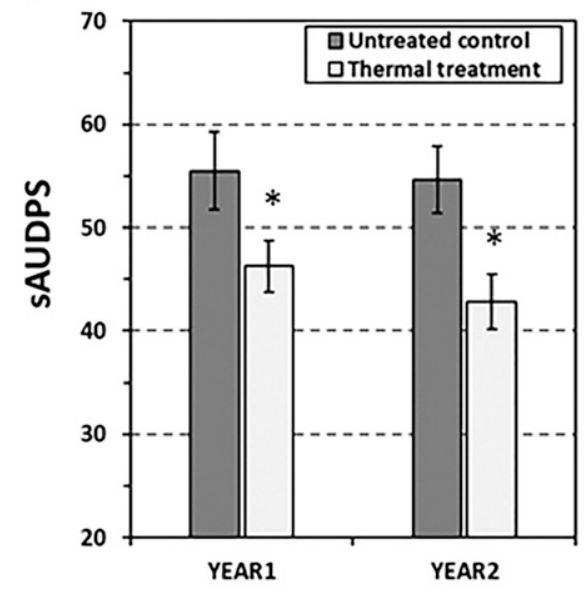

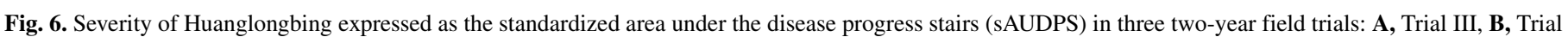

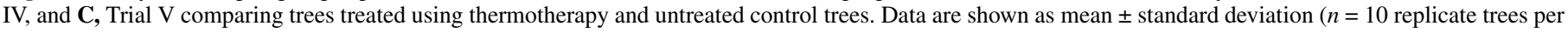
treatment). Asterisks $(*)$ indicate significant difference $(P<0.05$; Student's $t$ test, two-tailed) between the treatment and control.

A

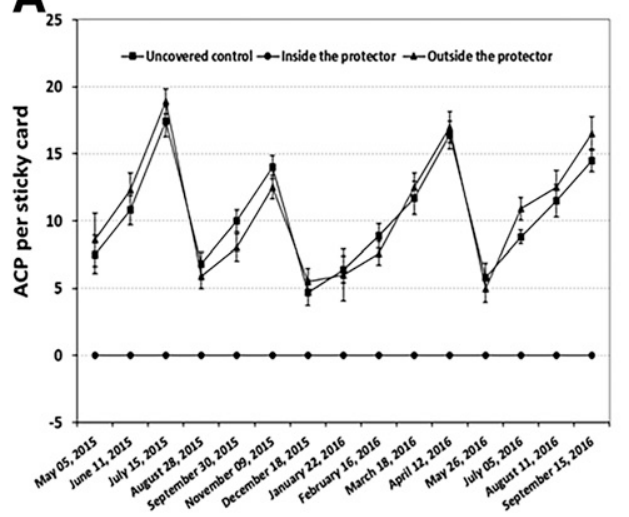

B

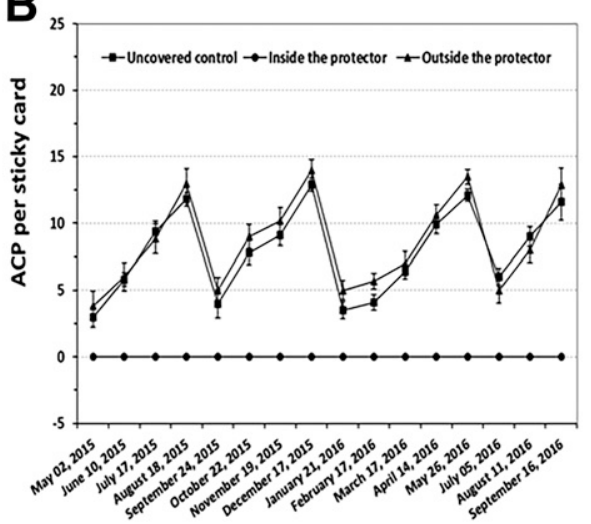

C

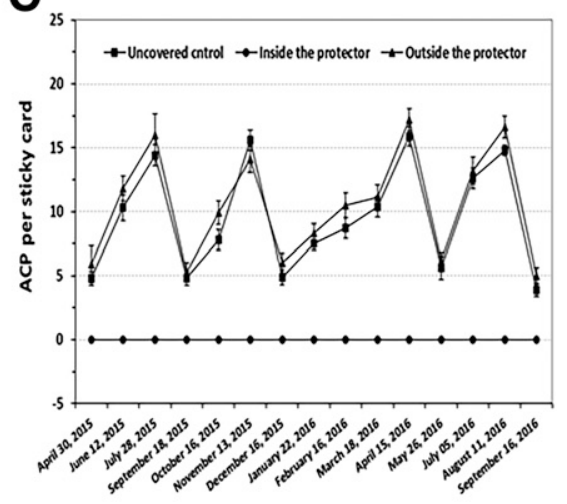

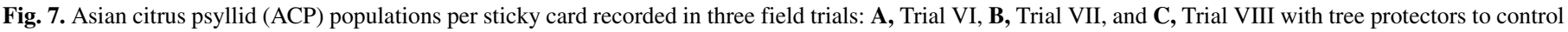

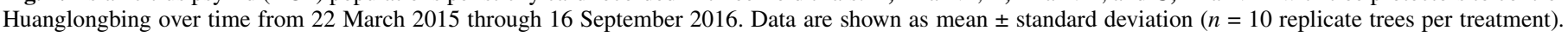

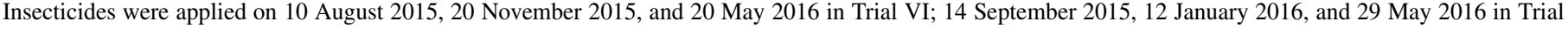
VII; and 20 August 2015, 30 November 2015, and 25 May 2016 in Trial VIII. 
Trunk injection is a target-precise method for delivery of compounds into plant and is more efficient than foliar spray (Aćimović et al. 2015, 2016; Hu and Wang, 2016). In the present study, Phi was foliar-sprayed at about $4.0 \mathrm{~g} /$ tree (4.7 liters/ha, 56\% active ingredient), and moves systemically once entering into the tree (Guest and Grant 1991; Orbović et al. 2008). But it may not reach a similar level inside the plant as that by trunk-injection at 1.0 $\mathrm{g}$ /tree sufficient for inducing resistance (Hu et al. 2018). Similarly, Gottwald et al. (2012) found that Phi applied by foliar spray did not reduce the Las titer or severity of HLB or increase fruit yield in field trials. Taken together, these results suggest that optimization of application rate of Phi is needed when applied by foliar spray to control citrus HLB.

The addition of both Phi-N and compost rather than Phi-N or compost alone to $\mathrm{BABA}+\mathrm{AA}$ or $\mathrm{BABA}+\mathrm{AA}+\mathrm{SA}$ improved their performance in maintaining fruit yield (Tables 1 and 2). The underlying mechanism is unknown and needs further characterization. Some slow conversion of Phi into phosphate $(\mathrm{Pi})$ in the soil and/or in the tree occurs by microorganism activity (Adams and Conrad 1953; Casida 1960; Malacinski and Konetzka 1966). In this study some foliar-applied Phi inevitably ran off into the soil. Compost applied to the soil contains millions of microorganisms. These microorganisms may facilitate the conversion of Phi to Pi in the soil resulting in more available $\mathrm{P}$ for the diseased tree, reducing $P$ deficiency related to HLB (Zhao et al. 2013). This idea is supported by the finding that applying phosphorus oxyanion solutions to HLB-diseased orange trees reduced HLB symptom severity and significantly improved fruit production in a 3-year field trial in Florida (Zhao et al. 2013). However, without the plant defense induced by BABA + AA (+SA), Phi-N and/or compost was not efficacious in controlling HLB compared with the WSC.

Compost alone did not maintain fruit yield. This was inconsistent with previous reports where compost treatment improved tree growth, health, and/or yield (Ozores-Hampton et al. 2015). Difference in citrus variety, tree age, application timing and rate, severity of HLB, and field conditions might explain the contrasting results. Further investigation is needed to establish the effect of compost.

Previous studies have shown that foliar sprays of urea enhance fruit yield in healthy citrus trees (Alberigo 1999; Al-Obeed et al. 2018). However, the addition of $0.5 \%$ urea to plant defense inducers did not improve their performance controlling HLB (Figs. 1 and 2; Tables 1 and 2). Further investigations are needed to understand the role of $\mathrm{N}$ supplements in relation to plant defense inducers for controlling HLB.

Our results showed that thermotherapy transiently repressed Las titer and HLB symptoms compared with the untreated control (Figs. 5 and 6). Previous studies (Hoffman et al. 2013) reported that continuous heat treatment $\left(40\right.$ to $\left.42^{\circ} \mathrm{C}\right)$ of HLB-diseased citrus seedlings reduced Las titer and HLB-associated symptoms under

TABLE 3. Percentage of citrus replants that were qPCR positive for 'Candidatus Liberibacter asiaticus' based on detection in leaf samples in three field trials where the replants were covered with protectors to prevent psyllid feeding and infection with Huanglongbing over the duration of the experiments from March 2015 to October $2017^{2}$

\begin{tabular}{|c|c|c|c|c|c|c|}
\hline \multirow[b]{2}{*}{ Treatment } & \multicolumn{3}{|c|}{ Protector covered } & \multicolumn{3}{|c|}{ Protector removed } \\
\hline & Sep. $2015(\%)$ & Feb. $2016(\%)$ & Aug. $2016(\%)$ & Nov. $2016(\%)$ & Mar. $2017(\%)$ & Oct. $2017(\%)$ \\
\hline \multicolumn{7}{|l|}{ Trial VI } \\
\hline$P_{t \text { test }}$ & NA & NA & 0.0163 & 0.0191 & 0.0097 & 0.0004 \\
\hline \multicolumn{7}{|l|}{ Trial VII } \\
\hline Covered trees & 0.0 & 0.0 & $0.0 \mathrm{~b}$ & $0.0 \mathrm{~b}$ & $8.0 \mathrm{~b}$ & $35.0 \mathrm{~b}$ \\
\hline Covered trees & 0.0 & 0.0 & $0.0 \mathrm{a}$ & $0.0 \mathrm{~b}$ & $0.0 \mathrm{~b}$ & $20.0 \mathrm{~b}$ \\
\hline Uncovered control & 0.0 & 0.0 & $20.0 \mathrm{a}$ & $40.0 \mathrm{a}$ & $80.0 \mathrm{a}$ & $100.0 \mathrm{a}$ \\
\hline$P_{t \text { test }}$ & NA & NA & 0.1161 & 0.0022 & 0.0012 & 0.0022 \\
\hline \multicolumn{7}{|l|}{ Combined } \\
\hline Covered trees & 0.0 & 0.0 & $0.0 \mathrm{~b}$ & $0.0 \mathrm{~b}$ & $6.0 \mathrm{~b}$ & $31.7 \mathrm{~b}$ \\
\hline Uncovered control & 0.0 & 0.0 & $31.7 \mathrm{a}$ & $45.0 \mathrm{a}$ & $73.3 \mathrm{a}$ & $98.3 \mathrm{a}$ \\
\hline
\end{tabular}

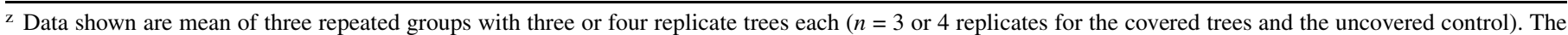
combined data are mean of all three trials with combined replicate trees ( $n=10$ replicates for covered trees and $n=10$ replicates for uncovered control). Values followed by different letters within each column in the same trial or the combined trials indicate significant difference $(P<0.05$; Student's $t$ test, two-tailed). NA: not applicable.

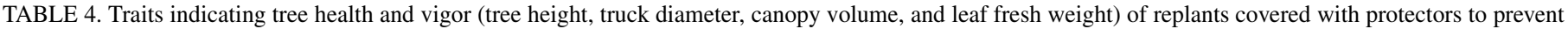
psyllid feeding and infection with Huanglongbing over the duration of the experiments from March 2015 to October $2017^{\mathrm{z}}$

\begin{tabular}{|c|c|c|c|c|}
\hline Treatment & Tree height $(\mathrm{cm})$ & Trunk diameter $(\mathrm{cm})$ & Canopy volume $\left(\mathrm{cm}^{3}\right)$ & Leaf fresh weight $(\mathrm{mg})$ \\
\hline \multicolumn{5}{|l|}{ Trial VI } \\
\hline Covered trees & $136.3 \pm 8.6 \mathrm{a}$ & $2.45 \pm 0.36 \mathrm{a}$ & $4,526.2 \pm 210.5 \mathrm{a}$ & $415.2 \pm 52.3 \mathrm{a}$ \\
\hline Uncovered control & $115.2 \pm 9.4 \mathrm{~b}$ & $2.24 \pm 0.23 \mathrm{a}$ & $3,198.7 \pm 196.4 b$ & $393.3 \pm 56.4 \mathrm{a}$ \\
\hline$P_{t \text { test }}$ & 0.045 & 0.442 & 0.008 & 0.216 \\
\hline \multicolumn{5}{|l|}{ Trial VII } \\
\hline Covered trees & $142.6 \pm 7.2 \mathrm{a}$ & $2.54 \pm 0.31 \mathrm{a}$ & $4,625.4 \pm 229.5 \mathrm{a}$ & $408.4 \pm 36.5 \mathrm{a}$ \\
\hline Uncovered control & $123.9 \pm 8.7 \mathrm{~b}$ & $2.26 \pm 0.22 \mathrm{a}$ & $3,598.8 \pm 202.6 b$ & $398.1 \pm 39.3 \mathrm{a}$ \\
\hline$P_{t \text { test }}$ & 0.043 & 0.487 & 0.007 & 0.368 \\
\hline \multicolumn{5}{|l|}{ Trial VIII } \\
\hline Covered trees & $150.8 \pm 8.5 \mathrm{a}$ & $2.65 \pm 0.18 \mathrm{a}$ & $5,825.6 \pm 362.5 \mathrm{a}$ & $443.9 \pm 59.1 \mathrm{a}$ \\
\hline Uncovered control & $124.2 \pm 6.8 \mathrm{~b}$ & $2.41 \pm 0.22 \mathrm{a}$ & $4,268.2 \pm 304.3 b$ & $388.6 \pm 38.5 \mathrm{a}$ \\
\hline$P_{t \text { test }}$ & 0.014 & 0.237 & 0.001 & 0.246 \\
\hline
\end{tabular}

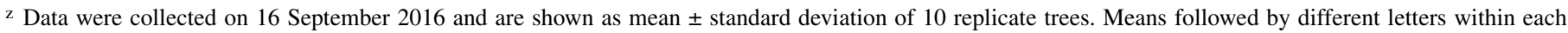
column in the same trial indicate significant difference $(P<0.05$; Student's $t$ test, two-tailed $)$. 
controlled conditions. Thermotherapy was also demonstrated effective in the field (Al-Jumaili and Ehsani 2015; Ehsani et al. 2016). The transient decline of Las titer indicates that multiple thermotherapy treatments may be required to maximize efficacy. Methods to deliver heat treatment to root systems are desirable to reduce or eliminate the reservoirs populations of Las in roots (Johnson et al. 2014; Tatineni et al. 2008). Thermotherapy can damage trees: we observed a reduction in yield in the first year due to heat induced fruit drop (data not shown), which has been noted in previous research (Al-Jumaili and Ehsani 2015). It remains to be determined whether a viable approach can be identified to revive severely diseased trees. Trunk injection of HLB-diseased trees with bactericides can be efficacious (Hu and Wang 2016; Hu et al. 2018) but is not approved on citrus.

Replanting is critical to replace dying trees (category 3) in a productive grove or to replace whole groves that are no longer profitable. Young citrus trees are reportedly more vulnerable than older trees to infection by Las, so it is critical to protect young trees from the vector (Gottwald 2010). Current measures for protecting young trees rely on application of insecticides to prevent Las from spreading (Bassanezi et al. 2013). Although new insecticides are being developed and released, the efficacy has been limited. Furthermore, psyllid populations have developed resistance to insecticides (Tiwari et al. 2011). As a result, effective control of ACP needs long term and frequent applications of insecticides. Extensive applications of insecticides have caused public concern about effects on nontarget organisms such as honeybees and environmental pollution in citrus orchards. Therefore, alternative methods to protect young trees from the vector are highly desirable. Croxton and Stansly (2014) reported metalized polyethylene mulch, and Schumann and Singerman (2016) tested a CUPS program, to prevent ACP from access to young citrus trees. Both reports suggested more in-depth investigation for practical application in the field. Our results showed that tree protectors exclude ACP and thus infection by Las (Table 3 ). In addition, Las was not detected in the replants within 3 months after removal of the protectors. Furthermore, the protector promoted tree growth (Table 4). Thus, protected trees may mature earlier than unprotected trees, which implies that they may develop tolerance to infection by Las earlier, and have a longer production life span. This would benefit the grower. Altogether, our observations, along with the earlier reports indicate value of using protectors in young citrus plantings threatened by HLB. It remains to be determined whether tree protectors are practical and can survive storms or hurricanes. In addition, the economic feasibility of using tree protectors needs to be evaluated, and their design would need optimizing for practical tree management.

In summary, our results suggest that the combination of plant defense inducers, nitrogen fertilizer, and compost had a positive effect suppressing Las titer in citrus plants and sustaining fruit productivity compared with the untreated control when applied to mildly infected trees (category 1$)$. Thermotherapy treatment $\left(55^{\circ} \mathrm{C}\right.$ for $2 \mathrm{~min}$ ) showed a suppressive effect on growth of Las and severity of symptoms of HLB in severely diseased trees (category 2), but the effect was transient. Finally, tree protectors exclude ACP from new plantings (replacing dying trees, category 3 ) and therefore infection by Las.

\section{LITERATURE CITED}

Aćimović, S., VanWoerkom, A., Garavaglia, T., Vandervoort, C., Sudin, G. W., and Wise, G. C. 2016. Seasonal and cross-seasonal timing of fungicide trunk injections in apple trees to optimize management of apple scab. Plant Dis. 100:1606-1616.

Aćimović, S., Zeng, Q., McGhee, G., Sundin, G., and Wise, J. 2015. Control of fire blight (Erwinia amylovora) on apple trees with trunk-injected plant resistance inducers and antibiotics and assessment of induction of pathogenesis-related protein genes. Front. Plant Sci. 6:16.
Adams, F., and Conrad, J. P. 1953. Transition of phosphite to phosphate in soils. Soil Sci. 75:361-371.

Al-Jumaili, A., and Ehsani, R. 2015. Mobile batch heat treatment system for treating HLB-infected citrus trees. ASABE Annual International Meeting, Paper No. 152190319.

Al-Obeed, R. S., Ahmed, M. A., Kassem, H. A., and Al-Saif, A. M. 2018. Improvement of "Kinnow" mandarin fruit productivity and quality by urea, boron and zinc foliar spray. J. Plant Nutr. 41:609-618.

Alberigo, L. G. 1999. Effects of foliar applications of urea or Nutriphite on flowering and yields of Valencia orange trees. Proc. Fla. State Hortic. Soc. 112:1-4.

Alvarez, S., Rohrig, E., Sol'1s, D., and Thomas, M. H. 2016. Citrus greening disease (Huanglongbing) in Florida: Economic impact, management and the potential for biological control. Agric. Res. 5:109-118.

Bassanezi, R. B., Montesino, L. H., Gimenes-Fernandes, N., Yamamoto, P. T., Gottwald, T. R., Amorim, L., and Bergamin Filho, A. 2013. Efficacy of area-wide inoculum reduction and vector control on temporal progress of Huanglongbing in young sweet orange plantings. Plant Dis. 97:789-796.

Belcher, A. 2017. Citrus greening plant disease detected in Alabama. Alabama Department of Agriculture and Industry. (Press release 20 June 2017). http://agi.alabama.gov/s/press-release's/citrus-greening-plantdisease-detected-in-alabama

Boina, D., and Bloomquist, J. 2015. Chemical control of the Asian citrus psyllid and of huanglongbing disease in citrus. Pest Manag. Sci. 71: 808-823.

Bové, J. M. 2006. Huanglongbing: A destructive, newly-emerging, century-old disease of citrus. J. Plant Pathol. 88:7-37.

Casida, L. E. 1960. Microbial oxidation and utilization of orthophosphite during growth. J. Bacteriol. 80:237-241.

Cipollini, D., Purrington, C., and Bergelson, J. 2003. Costs of induced responses in plants. Basic Appl. Ecol. 4:79-89.

Coletta-Filho, H. D., Targon, M. L. P. N., Takita, M. A., De Negri, J. D., and Pompeu, J. 2004. First report of the causal agent of Huanglongbing ("Candidatus Liberibacter asiaticus") in Brazil. Plant Dis. 88:1382.

Croxton, S. D., and Stansly, P. A. 2014. Metalized polyethylene mulch to repel Asian citrus psyllid, slow spread of huanglongbing and improve growth of new citrus plantings. Pest Manag. Sci. 70:318-323.

Ehsani, R., Dewdney, M., and Johnson, E. 2016. Controlling HLB with thermotherapy: What have we learned so far? Citrus Ind. 9:26-28.

Fu, Z. Q., and Dong, X. 2013. Systemic acquired resistance: Turning local infection into global defense. Annu. Rev. Plant Biol. 64:839-863.

Gottwald, T. R. 2010. Current epidemiological understanding of citrus Huanglongbing. Annu. Rev. Phytopathol. 48:119-139.

Gottwald, T. R, da Graça, J. V., and Bassanezi, R. B. 2007. Citrus Huanglongbing: The pathogen and its impact. Plant Health Progress. doi: 10.1094/PHP-2007-0906-01-RV.

Gottwald, T. R., Graham, J. H., Irey, M. S., McCollum, T. G., and Wood, B. W. 2012. Inconsequential effect of nutritional treatments on Huanglongbing control, fruit quality, bacterial titer and disease progress. Crop Prot. 36: 73-82.

Graham, J. H. 2011. Phosphite for control of Phytophthora diseases in citrus: model for management of Phytophthora species on forest trees? N. Z. J. For. Sci. 41S:S49-S56.

Guest, D., and Grant, B. 1991. The complex action of phosphonates as antifungal agents. Biol. Revenues 66:159-187.

Halbert, S. E. 2005. The discovery of Huanglongbing in Florida. Page H-3 in: Proceedings of the 2nd International Citrus Canker and Huanglongbing Research Workshop. Florida Citrus Mutual, Orlando, FL.

Heil, M., Hilpert, A., Kaiser, W., and Linsenmair, K. 2000. Reduced growth and seed set following chemical induction of pathogen defense: Does systemic acquired resistance (SAR) incur allocation costs? J. Ecol. 88: 645-654.

Hoffman, M. T., Doud, M. S., Williams, L., Zhang, M.-Q., and Ding, F. 2013. Heat treatment eliminates 'Candidatus Liberibacter asiaticus' from infected citrus trees under controlled conditions. Phytopathology 103:15-22.

$\mathrm{Hu}$, J., Jiang, J., and Wang, N. 2018. Control of citrus Huanglongbing via trunk injection of plant defense activators and antibiotics. Phytopathology 108: 186-195.

Hu, J., and Wang, N. 2016. Evaluation of the spatiotemporal dynamics of oxytetracycline and its control effect against citrus Huanglongbing via trunk injection. Phytopathology 106:1495-1503.

Johnson, E. G., Wu, J., Bright, D. B., and Graham, J. H. 2014. Association of 'Candidatus Liberibacter asiaticus' root infection, but not phloem plugging with root loss on huanglongbing-affected trees prior to appearance of foliar symptoms. Plant Pathol. 63:290-298.

Lee, J. A., Halbert, S. E., Dawson, W. O., Robertson, C. J., Keesling, J. E., and Singer, B. H. 2015. Asymptomatic spread of huanglongbing and implications for disease control. Proc. Natl. Acad. Sci. USA 112:7605-7610. 
Li, J., Pang, Z., Trivedi, P., Zhou, X., and Ying, X. 2017. 'Candidatus Liberibacter asiaticus' encodes a functional salicylic acid (SA) hydroxylase that degrades SA to suppress plant defenses. Mol. Plant-Microbe Interact. 30:620-630.

Li, J., Trivedi, P., and Wang, N. 2016. Field evaluation of plant defense inducers for the control of citrus Huanglongbing. Phytopathology 106:37-46.

Malacinski, G., and Konetzka, W. A. 1966. Bacterial oxidation of orthophosphite. J. Bacteriol. 91:578-582.

National Academies of Sciences, Engineering, and Medicine. 2018. A Review of the citrus greening research and development efforts supported by the Citrus Research and Development Foundation: Fighting a ravaging disease. The National Academies Press, Washington, DC.

Orbović, V., Syvertsen, J. P., Bright, D., Van Clief, D. L., and Graham, J. H. 2008. Citrus seedling growth and susceptibility to root rot as affected by phosphite and phosphate. J. Plant Nutr. 31:774-787.

Ozores-Hampton, M., Adair, R. C., Jr., and Stansly, P. A. 2015. Using compost in citrus. Citrus Ind. 12:8-11.

Rouse, E. R., Ozores-Hampton, M., Roka, F., and Roberts, P. 2017. Rehabilitation of Huanglongbing-affected citrus trees using severe pruning and enhanced foliar nutritional treatments. HortScience 52:972-978.

Schumann, A., and Singerman, A. 2016. The economics of citrus under cover production systems and whole tree thermotherapy. Citrus Ind. 2016:14-18.

Shen, W., Cevallos-Cevallos, J. M., Da Rocha, U. N., Arevalo, H. A., Stansly, P. A., Roberts, P. D., and van Bruggen, A. H. C. 2013. Relation between plant nutrition, hormones, insecticide applications, bacterial endophytes, and Candidatus Liberibacter $\mathrm{Ct}$ values in citrus trees infected with Huanglongbing. Eur. J. Plant Pathol. 137:727-742.

Simko, I., and Piepho, H. 2012. The area under the disease progress stairs: calculation, advantage, and application. Phytopathology 102:381-389.

Stansly, P. A., Arevalo, H. A., Qureshi, J. A., Jones, M. M., and Hendricks, K. 2014. Vector control and foliar nutrition to maintain economic sustainability of bearing citrus in Florida groves affected by Huanglongbing. Pest Manag. Sci. 70:415-426.

Tansey, J. A., Vanaclocha, P., Monzo, C., Jones, M., and Stansly, P. A. 2017. Costs and benefits of insecticide and foliar nutrient applications to huanglongbing-infected citrus trees. Pest Manag. Sci. 73:904-916.
Tatineni, S., Sagaram, U. S., Gowda, S., Robertson, C. J., Dawson, W. O., Iwanami, T., and Wang, N. 2008. In planta distribution of 'Candidatus Liberibacter asiaticus' as revealed by polymerase chain reaction (PCR) and real-time PCR. Phytopathology 98:592-599.

Tiwari, S., Mann, R. S., Rogers, M. E., and Stelinski, L. L. 2011. Insecticide resistance in field populations of Asian citrus psyllid in Florida. Pest Manag. Sci. 67:1258-1268.

Trivedi, P., Sagaram, U. S., Kim, J. S., Brlansky, R. H., Rogers, M. E., Stelinski, L. L., Oswalt, C., and Wang, N. 2009. Quantification of viable 'Candidatus Liberibacter asiaticus' in hosts using quantitative PCR with the aid of ethidium monoazide (EMA). Eur. J. Plant Pathol. 124:553-563.

Trivedi, P., Spann, T., and Wang, N. 2011. Isolation and characterization of beneficial bacteria associated with citrus roots in Florida. Microbiol. Ecol. 62:324-336.

Walters, D., Ratsep, J., and Havis, N. 2013. Controlling crop diseases using induced resistance: Challenges for the future. J. Exp. Bot. 64:1263-1280.

Wang, N., Pierson, E. A., Setubal, J. C., Xu, J., Levy, J. G., Zhang, Y., Li, J., Rangel, L. T., and Martins, J., Jr. 2017. The Candidatus Liberibacter-host interface: Insights into pathogenesis mechanisms and disease control. Annu. Rev. Phytopathol. 55:20.1-20.32.

Wang, N., and Trivedi, P. 2013. Citrus Huanglongbing: A newly relevant disease presents unprecedented challenges. Phytopathology 103:652-665.

Xu, M., Liang, M., Chen, J., Xia, Y., Zheng, Z., Zhu, Q., and Deng, X. 2013. Preliminary research on soil conditioner mediated citrus Huanglongbing mitigation in the field in Guangdong, China. Eur. J. Plant Pathol. 137:283-293.

Yang, C., Powell, C. A., Duan, Y.-P., Shatters, R., and Zhang, M. 2015. Antimicrobial nanoemulsion formulation with improved penetration of foliar spray through citrus leaf cuticles to control citrus Huanglongbing. PLoS One 10:e 0133826.

Zhao, H., Sun, R., Albrecht, U., Padmanabhan, C., Wang, A., Coffey, M. D., Girke, T., Wang, Z., Close, T. J., Roose, M., Yokomi, R. K., Folimonova, S., Vidalakis, G., Rouse, R., Bowman, K. D., and Jin, H. 2013. Small RNA profiling reveals phosphorus deficiency as a contributing factor in symptom expression for citrus Huanglongbing disease. Mol. Plant 6:301-310. 